\section{DIGITAL COMMONS \\ @ UNIVERSITY OF SOUTH FLORIDA}

\section{ABO: Interactive Journal for Women in the Arts, 1640-1830}

Volume 6

Issue 1 Volume 6.1 (Spring 2016)

Article 4

2016

\title{
Review of Sarah Raff, Jane Austen's Erotic Advice
}

Danielle Spratt

California State University, Northridge, danielle.spratt@csun.edu

Follow this and additional works at: https://digitalcommons.usf.edu/abo

Part of the Dramatic Literature, Criticism and Theory Commons, Educational Methods Commons, Feminist, Gender, and Sexuality Studies Commons, and the Literature in English, British Isles Commons

\section{Recommended Citation}

Spratt, Danielle (2016) "Review of Sarah Raff, Jane Austen's Erotic Advice," ABO: Interactive Journal for Women in the Arts, 1640-1830: Vol.6: Iss.1, Article 4.

http://dx.doi.org/10.5038/2157-7129.6.1.4

Available at: https://digitalcommons.usf.edu/abo/vol6/iss1/4

This Reviews is brought to you for free and open access by Digital Commons @ University of South Florida. It has been accepted for inclusion in ABO: Interactive Journal for Women in the Arts, 1640-1830 by an authorized administrator of Digital Commons @ University of South Florida. For more information, please contact digitalcommons@usf.edu. 


\title{
Review of Sarah Raff, Jane Austen's Erotic Advice
}

\author{
Abstract \\ A book review of Sarah Raff's Jane Austen's Erotic Advice. \\ Keywords \\ Sarah Raff, Jane Austen's Erotic Advice, Janeite, Janeism, narrator, quixotism \\ Creative Commons License \\ cc) (1) $\odot$
}

This work is licensed under a Creative Commons Attribution-No Derivative Works 3.0 License. 
Sarah Raff, Jane Austen's Erotic Advice. New York: Oxford UP, 2014. Vii + 201pp. ISBN: 978-0199760336

Reviewed by Danielle Spratt

California State University, Northridge

At the end of her deft study of Janeite culture, Claudia Johnson playfully enumerates the range of goods produced for the Jane Austen "marketplace" and wonders how Austen's "power to sell — and to sell not merely her novels but also knickknacks - [proves] how right James was when he observed that 'our dear, everybody's dear Jane' served a very 'material purpose"' (181). We might emend this long list, one that ranges from Austen action figures and bumper stickers to thimbles and tea strainers, to include the Jane Austen bandage, which Amazon advertises with the clever question "[Who] better to protect your wounds than an author synonymous with the romance of the landed gentry?" While the Jane Austen bandage might seem simply to be another instance of tongue-incheek Austen kitsch, it offers a potent physical representation of what Sarah Raff's new work characterizes as the fundamentally palliative, "profoundly compensatory and reparative" nature of Austen's writing (4).

With exquisitely patient and often revelatory close readings of the novels published in and after 1815, Raff's compellingly titled Jane Austen's Erotic Advice accounts for the dynamic, intensely felt relationship between Austen's narrator and her readers, or what Johnson calls the Janeite "presumption of - or is it an aspiration to? - intimacy" (10). Raff compares the relationship between Austen's narrator and her reader to that of Pygmalion and Galatea, a model that demonstrates the mutually constitutive relationship between instruction and seduction. In so doing, Erotic Advice offers an important revision of traditional "rise of the novel" narratives: the anti-quixotism of much novel writing during the eighteenth century capitalized on the false binary between didactic novels and, to use William Warner's term, "novels of amorous intrigue" in order to seduce the reader more thoroughly (93). According to Raff,

novelists were convinced that it was by seducing the reader that they could most thoroughly teach her[.] ... Before Austen, the quixote wishes to be the kind of person who has the kind of adventures that deserve a place in the book she loves. The quixotic reader of Austen, by contrast, follows cues in the novel because she wants to become the creature of its author. $(23,28)$

Raff's study frames this insight by paralleling Austen's novelistic narrator with her troubled role as her niece Fanny Knight's romantic advisor, a gesture that indulges the Janeite penchant for authorial biography at the same time that it offers a skillful balance between formalist and psychoanalytic study.

In chapter one, Raff accounts for the construction of this erotic relationship between the narrator's Pygmalion and the Galatean reader by considering how Austen's narrative voice proffers epistemological certainty as the foundation of their relationship. By 
focusing on the imaginative value of the generalization, offered as a kind of advice to the reader, Austen's narrator encourages her audience

to pause to furnish [the literary generalization] with personal particulars that it can then interpret. ... Bridging real and fictional worlds, generalizations act as levers on which material from one realm slides into the other. They encourage the superimposition of fiction's semiotic code upon everyday life that misleads quixotes into madness or sexual transgression. (16)

Here, Raff asks us to revisit another standard understanding of eighteenth-century novel: rather than relying on particulars of characterization or setting, the genre's often didactic narrators increasingly deployed these generalizable maxims in order to create an intimate relationship between print and person.

Chapter two, an analysis of Pride and Prejudice, distinguishes the role of Austen's early narrator from that of her Fanny Knight-inspired post-1814 narrative voice. Austen's most well-known novel "subordinates the author/reader relationship to the romance among characters that works to illustrate it. ... The novel generates love that readers experience not in their own persons but in that of Elizabeth Bennet and bestow not on Austen but Mr. Darcy" (40-41). Raff tracks the "vanishing" presence of the narrator by analyzing how the novel's famous opening lines, at first read earnestly, then read with irony, ultimately revert to a kind of generalizable and verifiable truth-claim: "Famously, each of Pride and Prejudice's rich men does in fact want a wife" (55). Perhaps most exciting in this chapter is Raff's beautifully crafted study of the important role of Mr. Collins in the narrative. Moving beyond his function as plot device (the heir to Netherfield) or comedic relief (his botched proposal to Elizabeth and his sycophantic relationship with Lady Catherine de Bourgh), Raff compellingly situates Collins as an important template for both the reader and Elizabeth herself: "Ignorant of general opinion, Mr. Collins lives in a world of unknown laws that he dreads to break. . . . Elizabeth, like her cousin, comes to imagine herself judged by a foreign, authoritative, punishing consensus, one it is only possible to contemplate because she has been assured it approves of her" (51-52). Raff's exploration of the fictitious familial dynamic here nicely foreshadows the last three chapters' exploration of Austen's own epistolary family dynamic with Fanny.

Chapter three demonstrates the emotionally compensatory function of Austen's later narrator, reading Emma as a revisionary response to Austen's infamous advice that Fanny reject the advances of John Pemberton Plumptre. Raff writes,

The letters to Fanny stage an encounter between Austen and the UrJaneite. When Austen amended that encounter in Emma, she invited future readers to adopt the wishes it had generated. . . . Austen becomes the author of the reader's happy love life, but only because both members of the couple she arranges love Austen best of all. (63) 
The triangulation of desire founded on and manipulated by Austen's narrator is replicated within the novel by Emma's imagined understanding of her role as Highbury matchmaker, as well as beyond the novel via Austen's letters to Fanny. As in the previous chapter, here Raff considers a crucial moment of the narrator's intervention: the moment when she cuts off the reported discourse of Knightley's proposal and addresses her reader directly. Raff reads this moment as a fictitious means of encouraging a match (that between Knightley and Emma) that imaginatively corrects her epistolary advice to Fanny Knight, which actively discouraged the union between Fanny and Pumptre. Raff concludes that in addressing Fanny, the original Janeite, in this manner, Austen created a narrative presence that ultimately constructs Janeism as “Austen's own loving, remorseful, scornful, triumphant invention. The infallible matchmaker so dear to biographers was born of an error-prone intervention, but she was Austen's choice" (99). This chapter, along with the virtuoso readings performed chapter five, demonstrates most compellingly why it is valuable to read Austen's epistolary correspondence to Fanny alongside Austen's novels themselves.

In chapter four, Raff considers how Northanger Abbey provides Austen with another attempt to encode her narrative presence with addresses that soothe her niece. Raff reads Henry Tilney as the fictitious proxy for Austen's narrator herself, noting that just as Henry's gothic tale seduces and predicts Catherine Morland's behavior, so too does the narrator attempt to persuade and create an ideal, quixotic Galatea, one that addresses Fanny and the nebulous Janeite reader as well. In so doing, Austen creates a set of performances that "accus[e] orthodox novelists of bad faith, of aiming to seduce where they profess to protect" (104). While these relationships revise claims about the intellectual and emotional functions of the novel as a genre, they also allow Austen to perform yet another intimate revision of her correspondence with Fanny: "By figuring Fanny both as Northanger Abbey's reader and as that unrealistic ideal heroine whom the narrator declines to write about, Austen casts a backward glance on the far less flattering roles that Emma had allotted to Austen's niece" (128).

While each chapter in Raff's analysis demonstrates the value of her unique methodology, chapter five yields the most impressive results. Raff identifies what she calls the "erotics of mutual application" at work in Persuasion (130). Replacing the aims of the didactic eroticism she locates in Austen's previous works, the erotics of mutual application seek not intellectual accord, but rather a shared association of ideas, or a parallel intellectual process: "two lovers' application of the same particular to a general idea produces a frisson simulating physical touch, which in turn initiates a 'request or appeal' for love or marriage" (131). To demonstrate Austen's revised narrative presence, Raff reclaims the importance of a triad of matrons in the novel — Lady Russell, Mrs. Smith, and Nurse Rooke - and shows how Anne and Austen's narrator indict the matrons' attempts at persuading others to behave according to their own didactic aims. While this indictment allows Anne to recover her own erotic and emotional agency, it simultaneously invokes "the treatment that Austen the author has given Fanny, that reader-character whom she means to nurse" (150). Raff argues that Austen most clearly offers this new model of mutual application for both character and narrator in the famous scene in which Wentworth writes to Anne and responds to her claims as he listens to Anne and 
Harville's argument about the relationship between gender and emotional fidelity: "This scene, like the central love story itself, 'collapses' the period of time intervening between past and present. Author and reader, Anne and Wentworth, past and present are now applied to one another, touching, attached" (160). Raff continues, "The scene advances the proposal that Austen's writing and our reading are charged with reciprocal communication, so that the author learns and absorbs and answers the reader's applications as they take place" (160-161). The erotics of mutual application, Raff suggests, best allows Austen's narrator to address the unique circumstances of the twenty-first-century Janeite, while two-hundred years prior it also allowed Austen to revise her epistolary relationship with Fanny Knight one final time, through a gesture that empowered Fanny to decide on her own romantic choices.

Through an impressive balance of formal, theoretical, and biographical readings, Jane Austen's Erotic Advice offers its own corrective to those who are critical of Regency ball re-enactors. Rather than evincing an anxiety over the pop-culture consumption of Janeite kitsch, Raff's work shows us how the complex rhetorical functions of Austen's narrator ultimately anticipate and encourage us to sport a Jane Austen bandage as a material echo of "the cures and consolations of Austen's final novels", which create and create again a community of readers bound together by the valuable ways in which generalizable advice can blend fact and fiction, past and present, and author and reader (163). 


\section{Works Cited}

“Accoutrements Jane Austen Bandages.” Amazon.com. Web. 1 February 2016. $<\mathrm{http}: / / \mathrm{www}$.amazon.com/5Star-TD-Accoutrements-Jane-AustenBandages/dp/B00SVDCN8A>

Johnson, Claudia L. Jane Austen's Cults and Cultures. Chicago: U of Chicago P, 2012. Print.

Warner, William B. Licensing Entertainment: The Elevation of Novel Reading in Britain, 1684-1750. Berkeley: U of California P, 1998. Print. 